LANGUAGE FEATURES OF TEACHER'S TALK IN TEACHING PROCEDURE TEXT FOR THE TWELFTH GRADE OF SENIOR HIGH SCHOOL AT SMA SWASTA TUNAS PELITA BINJAI

AN ARTICLE

Submitted as the Partial Fulfillment of the Requirements for the Degree of Sarjana Pendidikan

By:

SISKA RAHAYU

Registration Number: 2122121039

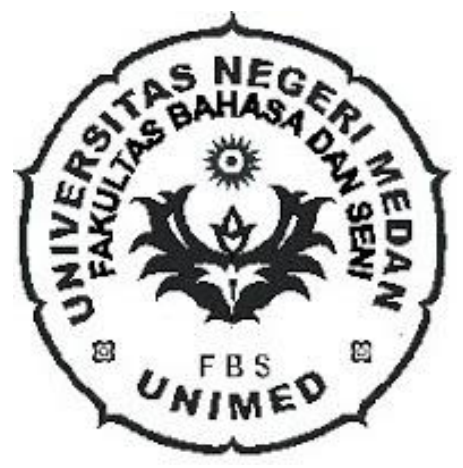

ENGLISH AND LITERATURE DEPARTMENT

FACULTY OF LANGUAGES AND ARTS

STATE UNIVERSITY OF MEDAN 


\title{
ARTIKEL
}

\section{LANGUAGE FEATURES OF TEACHER'S TALK IN TEACHING PROCEDURE TEXT FOR THE TWELFTH GRADE OF SENIOR HIGH SCHOOL AT SMA SWASTA TUNAS PELITA BINJAI}

Disusun dan Diajukan oleh:

Siska Rahayu

NIM. 2122121039

\begin{abstract}
Telah diverifikasi dan dinyatakan memenuhi syarat untuk diunggah pada jurnal online
\end{abstract}

Medan, Februari 2017

\section{Menyetujui}

Dosen Pembimbing I

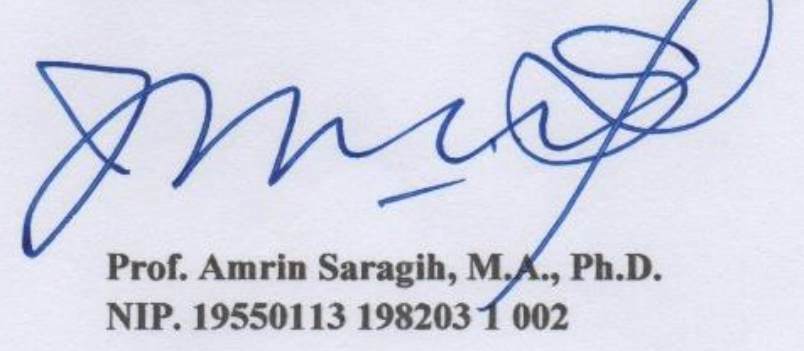

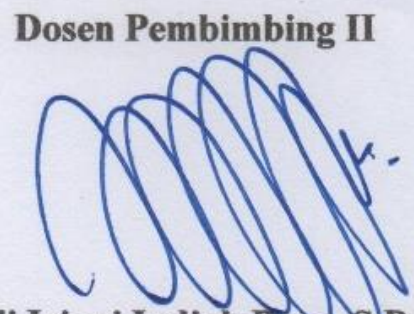

Isli Iriani Indiah Pane, SJPd., M.Hum. NIP. 197908022005012003

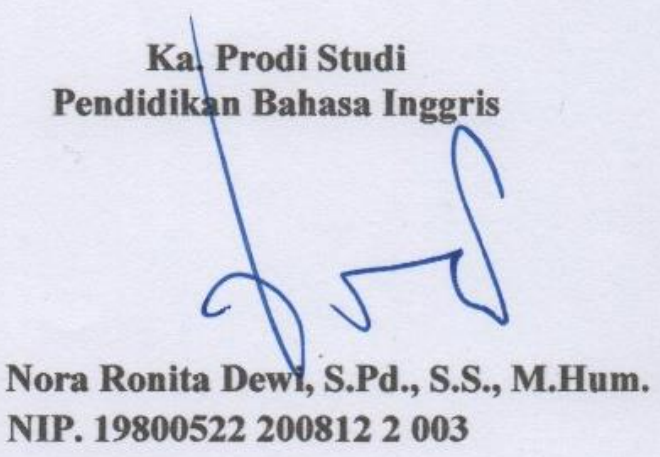




\title{
LANGUAGE FEATURES OF TEACHER'S TALK IN TEACHING PROCEDURE TEXT FOR THE TWELFTH GRADE OF SENIOR HIGH SCHOOL AT SMA SWASTA TUNAS PELITA BINJAI
}

\author{
*Siska Rahayu \\ **Prof. Amrin Saragih, M.A., Ph.D. \\ **Isli Iriani Indiah Pane, S.Pd., M.Hum.
}

\begin{abstract}
This study aims at analyzing features of teacher's talk in teaching procedure text. The data of the study were the script of utterances the teacher and students. The source of data were the twelfth grade of Senior High School at SMA Swasta Tunas Pelita Binjai where the teacher taught 27 students in one class. This study was used descriptive qualitative. SETT (Self Evaluation of Teacher Talk) framework used to identify and classified features of teacher talk during learning process which used video recording and field notes. The finding of the study showed that the dominant feature of teacher talk was extended leaner-turn $(41,6 \%)$. This feature effected on the students' learning process because the teacher gave the opportunity to the learners to deliver their ideas, it could improve the learners' speaking skill.
\end{abstract}

Keywords : Procedure Text, Features of Teacher Talk, Learning Process.

\footnotetext{
* Graduate Status

**Lecturer Status
} 


\section{INTRODUCTION}

\section{Background of the Study}

In the process of teaching English, teacher plays various pivotal roles. Harmer (2007: 25) states that the roles teacher performs includes: (1) controller to pupils, especially in grammar exercises and presentation/explanation, (2) prompter/motivator who encourages pupils, pushes them to achieve more, feeds in a bit of information or language to help them proceed, (3) assessor who tells the pupils how well they have done or gives them grades, etc., (4) resource whom pupils consult for difficult language items, etc. Therefore, when the teacher is able to master the roles, the students get success in learning process.

A major proportion of class time is taken up by teachers talking in front of the classroom (Nunan \& Bailey, 2009). No matter what teaching strategies or methods a teacher uses, it is necessary to give directions, explain activities and check students' understanding (Richards \& Schimdt, 1985). This clearly emphasizes the importance of teacher talk in language classrooms. Walsh (2011) claims that teacher talk is more important in language classroom than any other classroom since in this context the language being used by teacher is not only the means of acquiring new knowledge; it is also the goal of the study.

Walsh (2011) also claims that in language classrooms, teachers control patterns of communication, they are able to interrupt whenever they like, take the floor, hand over a turn, direct the discussion, and switch topics. All these functions are achieved through teacher talk. Teachers obtain their power and authority through effective language use. In fact, by the language they speak and the words 
they choose teachers not only manage their classrooms but also dominate and control learners' opportunities for language learning. Teachers take the floor and lead the class whenever they like through their speech. As Breen (1998) puts it, it is the teacher who orchestrates the interaction. Arguably, a teacher's ability to orchestrate the interaction not only determines who may participate and when, it also influences opportunities for learning. The consequence of this is that the teachers clearly talk more and occupy more of the interactional space of the classroom and learners' opportunities for classroom participation are largely controlled by the teachers. Yet, no matter how natural the dominance of teacher talk in language classrooms seems, for years, excessive teacher talk has been the source of criticism for restricting learners' opportunities of language production and classroom participation. Harmer (2007) claims that learners will have less opportunity for class participation if teacher talks and talks.

According to Yanfen and Zhao (2010), the interaction between teacher and students constitutes a most important part in all classroom activities. Appropriate teacher talk can create harmonious atmosphere and at the same time promotes a more friendly relationship between teacher and students, and consequently creates more opportunities for interactions between teachers and students.

Matsumoto (2010) indicated that the students want the teacher to use mother tongue as much as possible in classroom even they are studying English. However, the results of study indicated all the students allowed some classroom using English was only when it was hard for students to understand, only when 
grammar and difficult concepts were taught, or only when two languages were compared or only the meanings of difficult words are explained.

In the other hand, Rohmah (2011) investigated features of teacher talk using SETT framework. The result showed that features of teacher talk used by the teacher had been used to elicit students' contribution and assisted the students to build their speaking skill in learning process.

Many of students were difficult when studying English especially in speaking. Speaking was one productive skill of language learning. It involved communicative performance, and other important elements, such as, pronunciation, intonation, grammar, vocabulary, etc. Teacher should be taught in any language learning to make the learners able to communicate. Speaking was the skill that the learners will be judged upon most in real-life situation. It was an important part of everyday interaction and most often the first impression of a person was based on his/her ability to speak fluently and comprehensibly. Giving the text was one of strategy to improve students' ability especially in speaking.

\section{REVIEW OF LITERATURE}

Languages are generally taught and assessed in terms of the 'four skills': listening, speaking, reading, and writing. Darsini (2013:10) states that speaking skill is the productive skill in the oral mode. Like the other skill, speaking is more complicated that seems at first and involves more than just pronouncing words. There are five components of speaking skill that can be defined as follows: pronunciation, grammar, vocabulary, fluency and 
comprehension. To be a good speaker, learners have to master all of the components. However, besides those linguistic components above there are many factors that influence speaking ability.

Teacher talk is main important thing in teaching learning process. Teacher talk is the language in the classroom that takes up a major portion of class time employed to give directions, explain activities and check students' understanding (Sinclair \& Brazil, 1982:77).

Surtiati (2008:43) argues that teacher's talk takes place in a classroom setting between teachers and the students. Teachers tend to dominant talk in the classroom during teaching learning process. It happens because teachers have different purposes in the talks, such as: give an example; to become a model; to give an instruction etc. In general, teachers tend to dominate speech interaction in the classroom with their talk since each talk has different purposes. In the classroom's interaction takes place between teachers and students. Classroom interaction is important when teaching learning process ongoing. Classroom interaction is a practicing place that enhances the development of the two very important language skills which are speaking and listening among the learners. This device helps the learner to be competent enough to think critically and share their views among their peers.

Teachers talk occurs in the classroom setting between the teachers and the students in teaching and learning process. The interaction happens in the classroom usually not only in one to one interaction but also in one to many interactions depending on how many students involved in the teaching and learning process. 
Walsh (2006: 66) states that there are thirteen features of teacher talk occurs in interaction between the teacher and students in classroom, they are scaffolding, direct repair, content feedback, extended wait-time, referential question, seeking clarification, confirmation checks, extended learner turn, teacher echo, teacher interruption, extended teacher turn, and display question, turn completion and formfocused feedback.

\section{RESEARCH METHODOLOGY AND FINDINGS}

\section{Methodology}

This research used descriptive qualitative design. Fred and Perry (2005:75) states that qualitative research is characterized by verbal description as its data. It means that the data of the study analyzed by describing, identifying, and analyzing the texts. Descriptive research means that the data of this study are described or explained. Willig (2008:12) states that qualitative research can produce descriptions or explanations.

According to Locke (2007) qualitative research is interpretative research, with the inquirer typically involved in a sustained and intensive experience with participants. 


\section{Techniques of Analyzing the Data}

The data conducted for the twelfth grade of Senior High School. The data obtained as follows:

1. Identifying features of teacher talk from the script. The script was administered to the researcher to analyze features of teacher talk. The script alsol helped the researcher to transcribe the utterances of interaction between a teacher and the students in procedure text lesson.

2. Classifying the features of teacher talk. This stage was purposed to classify features of teacher talk based on SETT framework.

3. The calculation of the total features of teacher talk drew up in the table based on the SETT framework and the result of total features of teacher talk were made into percentages.

4. The data analysis interpreted descriptively.

\section{Findings}

After analyzing the transcript, the findings of this study could be seen below.

1. There were eleven features of teacher' talk occurred in teaching procedure text that extended learner-turn, extended wait-time, teacher turn, seeking clarification, referential question, display question, teacher echo, teacher interruption, direct repair, content feedback and scaffolding.

2. The result of the study showed that the dominant feature of teacher's talk was extended learner-turn $(41,6 \%)$. 


\section{CONCLUSION AND SUGGESTIONS}

\section{Conclusion}

After analyzing data, conclusions were drawn of the following:

1. Extended learner-turn as the dominant feature of teacher talk with the total was $85(41,6 \%)$ that occurred in teaching procedure text for the twelfth grade of Senior High School at SMA Swasta Tunas Pelita Binjai.

2. Teacher talk effected on the students' learning process because each of feature of teacher talk played important thing in classroom. Teacher contributed learners to deliver their information during learning process. It helped learners to improve their speaking skill.

\section{Suggestions}

In this occasion, this study would like to give some suggestions that might be useful for the teachers, the students, and everyone who read this study:

1. The teachers should keep training learners to contribute in classroom especially improving their speaking skill because we know that learners' speaking ability were lack and limited grammar.

2. For other researchers should conduct further studies on teacher talk, which has a very close reference to the students' needs.

\section{REFERENCES}


Darsini, N. W. (20012). Improving Speaking Skill Through Cooperative Learning Method of the Eight Grade Students. Mahasaraswati Denpasar University.

Lehman, F \& P, Jr. (2005). Research in Applied Linguistics. London. Lawrence Erlbaum Associates.

Harmer, J. (2007). How to Teach English. Harlow: Pearson Education Limited

Locke . (2007). Composing Qualitative Research : New York: Sage Publication, Inc.

Matsumoto, H. (2010). Students' Perceptions about Teacher Talk in Japanese as a Second Language Classes. Arizona Working Papers in SLA \&Teaching, 17, 53-74.

Nunan, D. (1991). Language Teaching Methodology. Cambridge: Cambridge University Press. . (1993). Introducing Discourse Analysis. London: The Pinguin Group.

- (2009). Exploring second language classroom research: A comprehensible guide.Boston: Heinle, Cengage Learning.

Richards, J. C. (2008). Teaching Listening and Speaking From Theory to Practice. New York: Cambridge University Press.

J. C., \& Schmidt, R. (1985). Longman Dictionary of Language Teaching \& Applied Linguistics. London: Pearson Education.

Rohmah, D. W. M. (2011). An Analysis of Teacher Talk to Teach Speaking Descriptive Text to the Seventh Graders of SMPN 1 Sidoarjo. A Journal. State University of Surabaya. Surabaya.

Sinclair, J. McH \& B, D. (1982). Teacher Talk. London: Oxford University Press.

Surtiati. (2008). Teacher's Scaffolding Talk in English Class at Senior High School. A Journal. State University of Semarang. Semarang.

Willig, C. (2008). Introducing Qualitative Research in Psychology. London. Open University Press.

Walsh, S. (2006). Investigating Classroom Discourse. New York: Routledge. 
(2011). Exploring classroom discourse: Language in action. London: Routledge.

Yan, X. (2006). Teacher Talk and EFL in University Classroom. Chongqing Normal University \& Yangtze Normal University. 